Article

\title{
Curvulin and Phaeosphaeride A from Paraphoma sp. VIZR 1.46 Isolated from Cirsium arvense as Potential Herbicides
}

\author{
Ekaterina Poluektova ${ }^{1}$, Yuriy Tokarev ${ }^{1}\left(\mathbb{D}\right.$, Sofia Sokornova $^{1}{ }^{\circledR}$, Leonid Chisty ${ }^{2}$, \\ Antonio Evidente ${ }^{3}$ and Alexander Berestetskiy ${ }^{1, *(D)}$ \\ 1 All-Russian Institute of Plant Protection, Podbelskogo 3, 196608 Pushkin, Russia; \\ e.poluektova@vizr.spb.ru (E.P.); ytokarev@vizr.spb.ru (Y.T.); svsokornova@vizr.spb.ru (S.S.) \\ 2 Research Institute of Hygiene, Occupational Pathology and Human Ecology, Federal Medical Biological \\ Agency, p/o Kuz'molovsky, 188663 Saint-Petersburg, Russia; mehrn.q2@gmail.com \\ 3 Department of Chemical Sciences, University of Naples Federico II, Complesso Universitario Monte S. \\ Angelo, Via Cintia 4, 80126 Napoli, Italy; evidente@unina.it \\ * Correspondence: aberestetskiy@vizr.spb.ru; Tel.: +7-(812)-4705110
}

Received: 8 October 2018; Accepted: 25 October 2018; Published: 28 October 2018

\begin{abstract}
Phoma-like fungi are known as producers of diverse spectrum of secondary metabolites, including phytotoxins. Our bioassays had shown that extracts of Paraphoma sp. VIZR 1.46, a pathogen of Cirsium arvense, are phytotoxic. In this study, two phytotoxically active metabolites were isolated from Paraphoma sp. VIZR 1.46 liquid and solid cultures and identified as curvulin and phaeosphaeride A, respectively. The latter is reported also for the first time as a fungal phytotoxic product with potential herbicidal activity. Both metabolites were assayed for phytotoxic, antimicrobial and zootoxic activities. Curvulin and phaeosphaeride A were tested on weedy and agrarian plants, fungi, Gram-positive and Gram-negative bacteria, and on paramecia. Curvulin was shown to be weakly phytotoxic, while phaeosphaeride A caused severe necrotic lesions on all the tested plants. To evaluate phaeosphaeride A's herbicidal efficacy, the phytotoxic activity of this compound in combination with five different adjuvants was studied. Hasten at $0.1 \%(v / v)$ was found to be the most potent and compatible adjuvant, and its combination with $0.5 \%(v / v)$ semi-purified extract of Paraphoma sp. VIZR 1.46 solid culture exhibited maximum damage to $C$. arvense plants. These findings may offer significant importance for further investigation of herbicidal potential of phaeosphaeride A and possibly in devising new herbicide of natural origin.
\end{abstract}

Keywords: Paraphoma sp. VIZR 1.46; curvulin; phaeosphaeride A; phytotoxins; herbicidal potential

\section{Introduction}

The search of new biologically active compounds and investigation of their mode of action is an important task for the development of new pesticides, including herbicides [1,2]. Natural products are the main sources of the molecules with new structures and original targets of action [3]. Natural phytotoxic metabolites can serve as lead compounds or as templates for the development of novel synthetic herbicidal agents and for mode of action studies [4,5]. Many have been isolated from fungal plant pathogens [6-8]. Phoma-like fungi include numerous plant pathogenic species and some of them were found to produce phytotoxic secondary metabolites. For instance, herbarumin I, a phytotoxin of Phoma herbarum, was reported as a highly effective inhibitor of the radicle growth of Amaranthus hypochondriacus seedlings [9]. Phytotoxins of Phoma macrostoma, macrocidin A and macrocidin B were found to be active ingredients of the extracts obtained from liquid culture of this fungus which are used as a bioherbicide for Canada thistle [10]. Phoma exigua var. exigua was 
proposed as a mycoherbicide for the biocontrol of the perennial weeds Sonchus arvensis and Cirsium arvense. When grown in liquid and solid cultures the fungus produced $p$-hydroxybenzaldehyde, cytochalasins B, F, Z2 and Z3, and deoxaphomin with potential herbicidal activity [11]. Two phytotoxic tetrasubstituted furopyrans, named chenopodolans A and B [12] and a phytotoxic unrearranged ent-pimaradiene, named chenopodolin [13], were isolated from culture filtrate of Phoma chenopodiicola, a pathogen of the annual weed Chenopodium album.

Besides the appropriate activity against the target species, natural herbicides are desired to be safe and selective for their direct use in crop protection [4,5,14-16]. Therefore, the wide range of bioassays should be used additionally to phytotoxicity testing of natural compounds. Moreover, the most of natural phytotoxins cannot overcome the cuticle barrier of the plant leaves and in many cases leaf wounding or infiltration are used to obtain a phytotoxic effect in currently used bioassays [17]. Efficient delivery of the active ingredient to the target sites of the plant is required to achieve phytotoxic effect.

A suitable adjuvant could increase the herbicide uptake by influencing leaf wettability, droplet contact area and penetration, following from reduced surface tension and contact angle of droplets on leaf surfaces $[17,18]$. Nonionic and anionic surface-active agents and various oils are the most used adjuvants $[18,19]$. Many research works have focused on using adjuvants to improve the efficacy of herbicide agents, so that their rates could be reduced [19]. Some solvents, for instance dimethylsulfoxide (DMSO), can also increase permeability of lipophilic molecules through the leaf cuticle [20]. Currently, there is no data available on the use of adjuvants together with natural phytotoxins to improve their activity on intact leaves of weeds.

Paraphoma sp. VIZR 1.46 strain (earlier reported as Phoma sp. No. 19) was isolated from leaves of Canada thistle (C. arvense). The extracts from solid and liquid culture of this fungus were shown to be phytotoxic and had different metabolic profiles [21]. In this paper, the production, isolation and biological characterization of phytotoxic metabolites produced by this fungus are described. Additionally, the effect of five commercial adjuvants was studied in order to evaluate the herbicidal potential of one of the main phytotoxins produced by Paraphoma sp. VIZR 1.46.

\section{Results and Discussion}

\subsection{Fungal Identification}

The fungus was isolated from diseased leaves of $C$. arvense. In vitro, the fungus did not sporulate on a range of agar media so molecular tools were used for its identification. Analysis of the nucleotide sequences of internal transcribed spacer (ITS), large subunit (LSU) and translation elongation factor (TEF) regions of DNA suggested that strain VIZR 1.46 is phylogenetically close to Phoma-like fungi, particularly, Paraphoma chrysanthemicola, Paraphoma radicina and Paraphoma vinacea. The phylogenetic tree of LSU was used for species of closely related genera to assess the placement of the isolates within the family Phaeosphaeriaceae [22] (see Supplementary Materials, Figures S1 and S2).

Based on a basic local alignment search tool (BLAST) search of National Center for Biotechnology Informations (NCBIs) GenBank nucleotide database sequences of Paraphoma sp. VIZR 1.46 were identical to P. chrysanthemicola CBS 522.66, P. radicina CBS 102,875 and P. vinacea UMPV 003. However, analysis of LSU region of these strains indicated that $P$. chrysanthemicola CBS 522.66, P. radicina CBS 102,875 and P. vinacea UMPV 003 were identical, while the sequence of our strain differed from them in four point mutations (see Supplementary Materials, Figure S3).

On oatmeal agar (OA) colony diameter reached $57 \mathrm{~mm}$ after two weeks; its pigmentation was olivaceous gray at the margin and dark red in the center while aerial mycelium was white grayish. On malt extract agar (MA) colony diameter was about $44 \mathrm{~mm}$ after two weeks; the pigmentation was dark gray at the margin and olivaceous gray in the center; aerial mycelium white grayish. Colony morphology was very similar to Paraphoma vinacea [23] and to Phoma sanguinolenta [24], both known as pathogens of some Asteraceae plants. 
Based on the molecular and morphological data the isolate VIZR 1.46 was placed to the genus Paraphoma. It was clearly shown that Paraphoma sp. VIZR 1.46 differs from the most common Phoma-like fungi hosted by C. arvense: Didymella cirsii (Phoma cirsii), Pleospora herbarum (Didymella herbarum), Boeremia hedericola (Phoma hedericola), Didymella macrostoma (Phoma macrostoma), Boeremia exigua and Plenodomus libanotidis (Phoma sanguinolenta; Leptosphaeria rubella), Stagonospora cirsii and Phyllosticta cirsii $[25,26]$. Some of these fungi are known as producers of phytotoxic metabolites: macrocidins [10], phyllostictines [26] and stagonolides [27]. Analysis of the ITS sequence of Paraphoma sp. VIZR 1.46 suggests that it significantly differs from Phyllosticta cirsii [28].

\subsection{Purification and Identification of Phytotoxins}

Fractionation of Paraphoma sp. VIZR 1.46 liquid culture extract (65 mg/L) by column chromatography (CC) and preparative thin layer chromatography (PTLC) gave the main phytotoxic metabolite $(1 \mathrm{mg} / \mathrm{L})$ as described in details in the Materials and Methods section. Curvulin (ethyl 2-(2-acetyl-3,5-dihydroxyphenyl)acetate) (Figure 1A) was identified by electrospray ionization mass spectrometry (ESI-MS), nuclear magnetic resonance (NMR) and ultraviolet (UV) spectroscopic methods (see Supplementary Materials, Figures S4-S7) with those (mass spectra (MS) and ${ }^{1} \mathrm{H}-$ and $\left.{ }^{13} \mathrm{C}-\mathrm{NMR}\right)$ reported in its isolation, together with $O$-methylcurvulinic acid, from Drechslera indica $[29,30]$. This fungus was proposed as a mycoherbicide for Portulaca oleracea, a spreading weed causing serious losses for important agrarian crops, such as cotton, corn, rice and potatoes. D. indica was also pathogen for Amaranthus spinosus, another noxious weed, and rape, a valuable source of cooking oil [31]. Curvulin had been previously isolated from Curvularia siddiqui and its structure in that time was characterized by chemical methods and infrared (IR) and UV spectra [30,31]. Curvularin was also isolated from Curvularia lunata together with methyl 2-acetyl-3,5-dihydroxyphenylacetate, methyl 2-acetyl-5-hydroxy-3-methoxyphenylacetate and 4-epiradicinol [32]. The identification of curvulin was also supported from the data from its ESI MS spectrum (Figure S5) which, beside the expected sodium cluster $[\mathrm{M}+\mathrm{Na}]^{+}$and the pseudomolecular ion $[\mathrm{M}+\mathrm{H}]^{+}$at $m / z 261$ and 239 , respectively, showed the significant fragmentation ions, not previously reported, at $m / z 211,197,193,165$ generated from the pseudomolecular ion by alternative loss of $\mathrm{C}_{2} \mathrm{H}_{4}, \mathrm{CH}_{2} \mathrm{CO}, \mathrm{C}_{2} \mathrm{H}_{5} \mathrm{OH}, \mathrm{C}_{2} \mathrm{H}_{5} \mathrm{CO}_{2} \mathrm{H}$, while the ion observed at $m / z 123$ was produced by the latter ion at $m / z 165$ by loss of $\mathrm{CH}_{2} \mathrm{CO}$. When curvulin was isolated from both Curvularia siddiqui and Curvularia lunata no any biological activity was reported but when it was more recently isolated from two Bipolaris strains and two Eichhornia macrophytes species, together with spirostaphylotrichin $\mathrm{R}$ and $\mathrm{U}$, the three metabolites showed antileishmanial activity [33]. However, this is the first report on the isolation of curvulin from a Paraphoma sp.
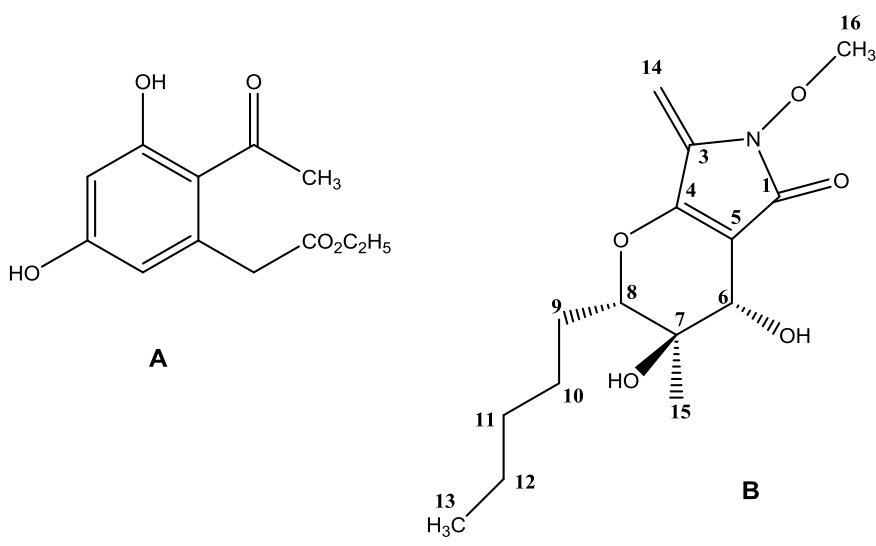

Figure 1. Structures of curvulin (A) and phaeosphaeride A (B).

The extract obtained from the solid culture of the fungus was fractionated by chromagraphic methods as described in the Materials and Methods section. It resulted in purification of another phytotoxic metabolite $(130 \mathrm{mg} / \mathrm{kg}) .{ }^{1} \mathrm{H}-$ and ${ }^{13} \mathrm{C}-\mathrm{NMR}$ data as well as mass 
spectrum of this compound are very similar to the data reported for phaeosphaeride A (3,4-dihydroxy-6-methoxy-3-methyl-7-methylene-2-pentyl-3,4,6,7-tetrahydropyrano[2-c]pyrrol-5(2H) -one) (Figure 1B), isolated from the endophyte FA 39 closely related to Phaeosphaeria avenaria as an inhibitor of STAT3-dependent signaling [34]. An extensive spectroscopic investigation was carried out in the present work, on the phaeosphaeride A isolated from Paraphoma sp. VIZR 1.46 and its ${ }^{1} \mathrm{H}$, hydrogen correlated spectroscopy $\left({ }^{1} \mathrm{H}-\mathrm{COSY}\right),{ }^{1} \mathrm{H}$, carbon heteronuclear multiple-quantum correlation $\left({ }^{13} \mathrm{C}-\mathrm{HMQC}\right)$, hydrogen and carbon heteronuclear multiple bond correlation $\left({ }^{1} \mathrm{H}-\right.$, $\left.{ }^{13} \mathrm{C}-\mathrm{HMBC}\right)$ and ${ }^{1} \mathrm{H}$, hydrogen rotating-frame Overhauser spectroscopy $\left({ }^{1} \mathrm{H}\right.$-ROESY) NMR spectra [35] (Supplementary Materials, Figures S13-S17) were carefully investigated. In particular, the ${ }^{1} \mathrm{H}-$, ${ }^{13} \mathrm{C}-\mathrm{HMBC}$ (Figure S15) showed that H-6 correlates to C-4, C-5 and C-8 and this confirmed the bicyclic structure of phaeosphaeride A, OH at C-7 correlates to $\mathrm{CH}_{3}-15, \mathrm{C}-8$ and $\mathrm{OH}$ at C-6 correlates to C-7. ${ }^{1} \mathrm{H},{ }^{1} \mathrm{H}$-COSY (Figure S13) data showed the same correlations for three spin systems as observed in phaeosphaeride A as reported by Maloney and colleagues [34] while ${ }^{1} \mathrm{H}-,{ }^{1} \mathrm{H}-\mathrm{ROESY}$ spectrum (Figures $\mathrm{S16}$ and $\mathrm{S17b}$ ) of phaeosphaeride A showed correlations between $\mathrm{CH}_{2}-14(\delta 4.98)$ and $\mathrm{CH}_{3}-16$ ( $\delta 3.80), \mathrm{H}-6(\delta 3.87)$ and H-8 ( $\delta 4.08)$ as observed and above reported in the nuclear Overhauser effect (NOE) ${ }^{1} \mathrm{H}-\mathrm{NMR}$ spectrum of in phaeosphaeride A [34] but differed as no correlation was noted between OH-7 ( 8 4.92) and OH-6 ( 85.42$)$.

The structure originally assigned to phaeosphaeride A from Maloney and co-workers was successively corrected as a result of the first synthetic attempts [36,37] and by its total enantioselective synthesis also carried out to investigate in more depth its biological activity and perform structure-activity relationships studies [38,39]. These results, which also allowed assigning its absolute configuration as reported in Figure 1B, were also supported from the crystallographic analysis carried out on the natural metabolites isolated from Phoma sp. (then reclassified as Paraphoma sp.) [40]. All the extensive synthetic and crystallographic work as well as the further biological investigation carried out on phaeosphaeride A and natural and synthetic analogues were recently reviewed [41].

The structure of phaeosphaeride A isolated from Paraphoma sp. VIZR 1.46 assigned to metabolite reported on the Figure 1B [41] was also supported by the data observed in its ESI MS spectrum (Figure S9), which showed, the expected sodium cluster $[\mathrm{M}+\mathrm{Na}]^{+}$, the pseudomolecular ion $[\mathrm{M}+\mathrm{H}]^{+}$ and the significant fragmentation ions, which are generated by this latter by successive losses of two water molecules $\left[\mathrm{M}+\mathrm{H}-\mathrm{H}_{2} \mathrm{O}\right]^{+}$and molecules $\left[\mathrm{M}+\mathrm{H}-2 \mathrm{H}_{2} \mathrm{O}\right]^{+}$, at $m / z 320,298,280$ and 262 , respectively.

There are other known phytotoxic spirocyclic $\gamma$-lactames, e.g., spirostaphylotrichines isolated from phytopathogenic fungi infecting wheat and some weeds from Poaceae [42]. Curvupallides are another group of structurally related metabolites produced by phytopathogenic fungus Curvularia pallescens [43]. Paraphaeosphaerides A-C isolated from Paraphaeosphaeria neglecta FT462 exhibit another group of structurally related compounds with different bioactive properties [44]. However, this is the first report on phaeosphaeride $\mathrm{A}$ as a potent fungal phytotoxin.

\subsection{Biological Activity}

Phytotoxic activity of curvulin and phaeosphaeride A was assayed on wounded leaf segments of C. arvense and Elytrigia repens. Both toxins caused necrotic lesions on leaves of the tested weeds within $24 \mathrm{~h}$ post treatment. The concentration of phaeosphaeride A required for induction of considerable leaf necrotic lesions (necrosis $\geq 2 \mathrm{~mm}$ in diameter) of $67 \mu \mathrm{M}$ and $84 \mu \mathrm{M}$ for C. arvense and E. repens, respectively. Curvulin showed significant phytotoxic activity at higher concentrations of $\geq 840 \mu \mathrm{M}$ (Figure 2). Weak phytotoxic activity of curvulin against $A$. spinosus and P. oleraceae was reported earlier [33]. 
Cirsium arvense

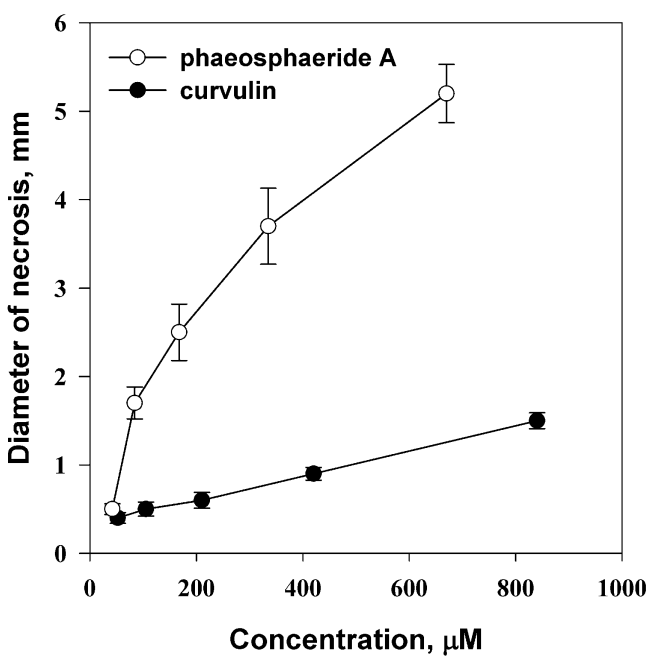

Elytrigia repens

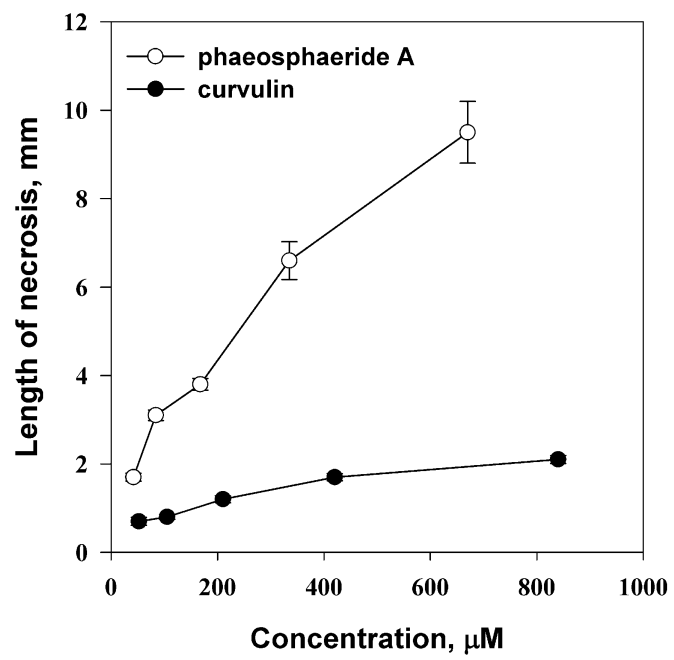

Figure 2. Phytotoxic activity of curvulin phaeosphaeride A for Cirsium arvense (left) and Elytrigia repens (right) in different concentrations. Bars indicate standard deviation at $p=0.05$.

Phytotoxic activity of phaeosphaeride A at $335 \mu \mathrm{M}$ concentration was not selective. Surprisingly, E. repens and Triticum aestivum (both from Poaceae family) were more sensitive to phaeosphaeride A than the host plant of the producing fungus, $C$. arvense (Figure 3). $C$. arvense and Pisum sativum were the most sensitive to curvulin at the concentration $840 \mu \mathrm{M}$ while other plant species were less susceptible to this toxin (Figure 3).

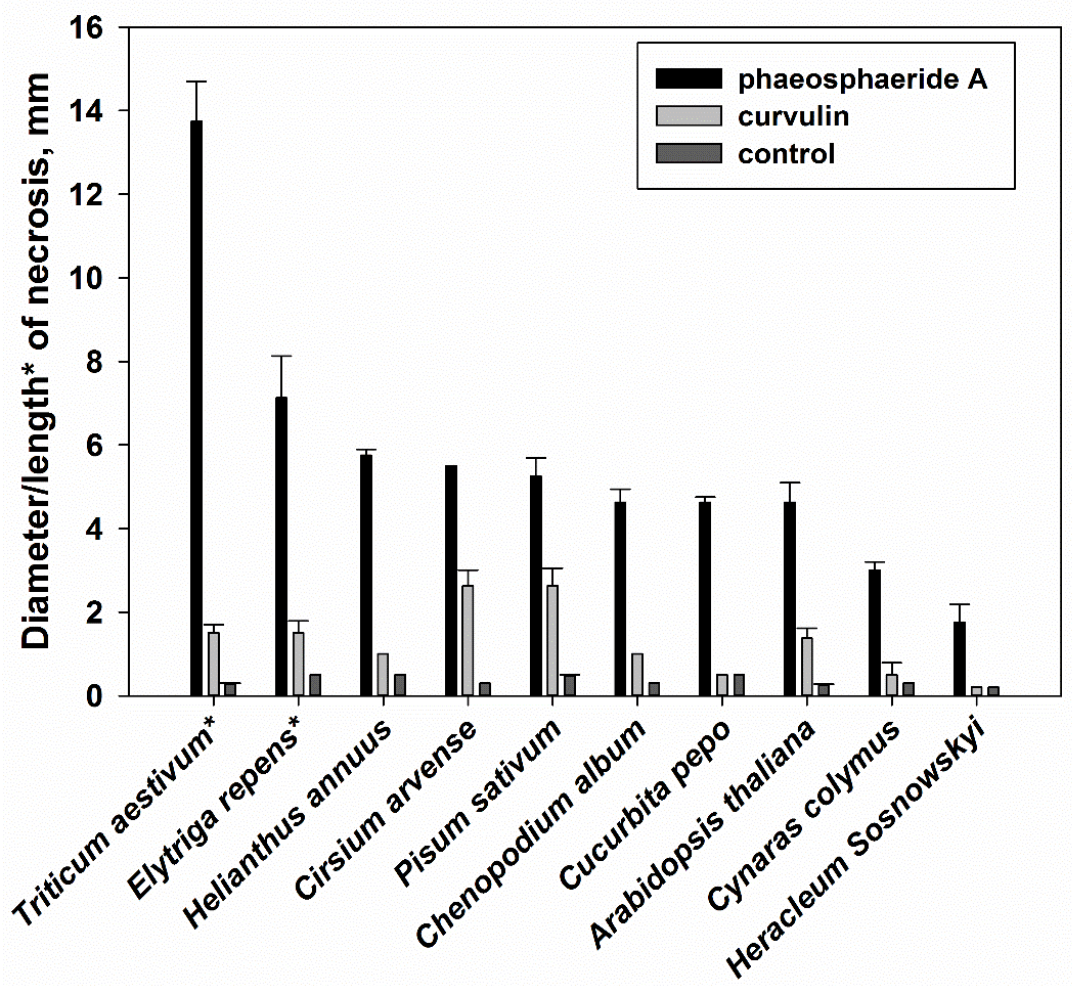

Figure 3. Phytotoxic selectivity of curvulin and phaeosphaeride A. tested at $840 \mu \mathrm{M}$ and $335 \mu \mathrm{M}$, respectively ( $10 \mu \mathrm{L} /$ leaf disc/leaf segment). Bars indicate standard deviation at $p=0.05$. The length of necrosis was measured when leaf segments of T. aestivum and E. repens were used, while for other plant species the diameter of the necrosis was estimated. 
At the maximal concentration of $1 \mathrm{mg} / \mathrm{mL}(335 \mu \mathrm{M})$ phaeosphaeride A inhibited root growth of seedling of lettuce, chicory and radish at the level about 50\% compared with control. At the concentration of $0.1 \mathrm{mg} / \mathrm{mL}$ the root growth of radish only was inhibited considerably (Figure 4).

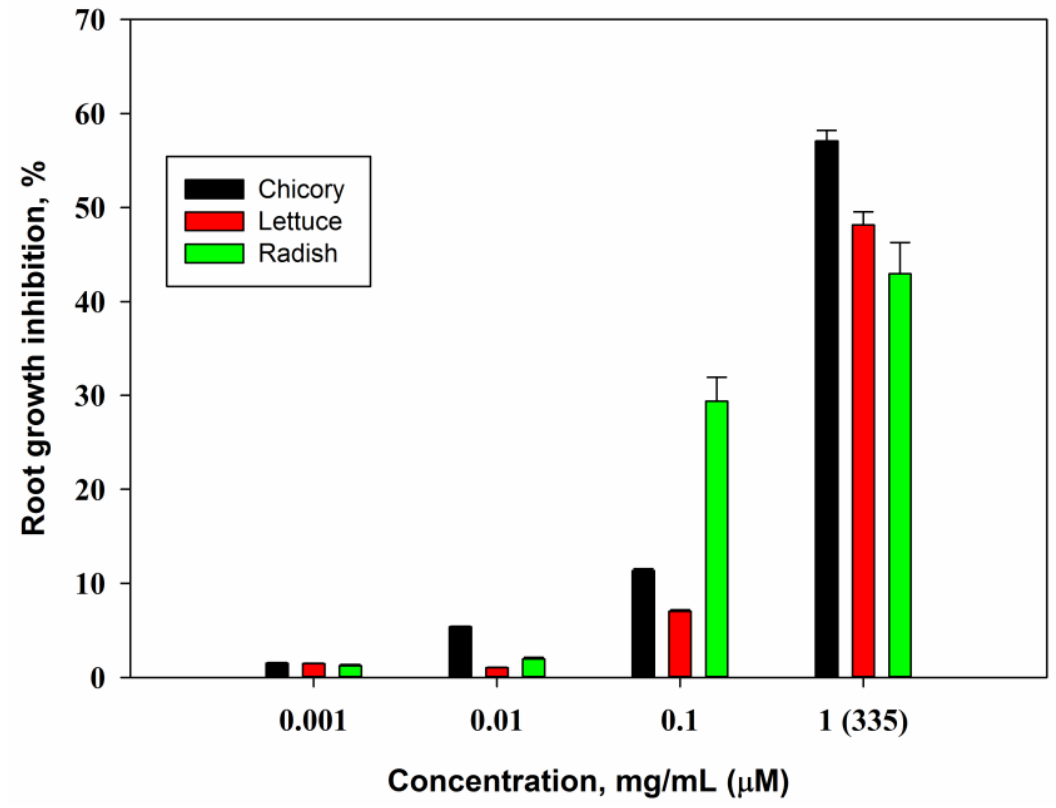

Figure 4. Phytotoxic activity of phaeosphaeride A in the root inhibition bioassay. Bars indicate standard deviation at $p=0.05$.

Curvulin was nontoxic in this bioassay at all the concentrations tested. It is known that many phytotoxins inhibit root growth, e.g., herbarumin I from P. herbarum and stagonolide A from $S$. cirsii demonstrated half maximal inhibitory concentration $\left(\mathrm{IC}_{50}\right)$ at the concentrations $50 \mu \mathrm{M}$ and $5 \mu \mathrm{M}$ respectively $[9,45]$. Comparing to these compounds the phytotoxic activity of phaeosphaeride $\mathrm{A}$ is weak. This level of phytotoxic activity of phaeosphaeride $\mathrm{A}$ is comparable to another tetramic acide derivative, spirostaphylotrichin A [42].

None of the two tested phytotoxins showed antimicrobial activity when assayed on the eight bacteria and two fungi at the concentration up to $100 \mu \mathrm{g} / \mathrm{disc}$. Curvulin was reported to lack antimicrobial activity against Escherichia coli, Staphylococcus aureus, Salmonella choleraesuis and Bacillus subtilis [29,33]. It was shown earlier that phaeosphaeride A (identified as phyllostictine B) has no antimicrobial and antifungal activity when tested on Geotrichum candidum, Lactobacillus sp. and E. coli [26].

Phaeosphaeride A was shown to be weakly toxic to Paramecia caudatum. At the relatively high concentration of $40 \mu \mathrm{M} \mathrm{40 \%}$ of ciliates stopped movement $3 \mathrm{~h}$ post treatment. These data were in accordance to negligible activity of this compound on brine shrimp (Artemia salina L.) larvae [26]. Curvulin was completely inactive to Paramecium caudatum.

\subsection{Effects of Leaf Wounding, Solvent and Adjuvants on Phytotoxic Activity of Phaeosphaeride A}

Analysis of variance showed significant effects of adjuvants $(p<0.001)$ as well as wounding $(p<0.001)$ on phytotoxic activity of phaeosphaeride A on leaf discs of $C$. arvense. The interaction of these factors was insignificant. Wounding the leaf discs of $C$. arvense gave at least 2-fold increase of phytotoxic activity of phaeosphaeride A comparing to its effect on the intact leaf discs (Figure 5). The effect of the solvent was pronounced only with a combination with the factor of leaf wounding $(p<0.001)$ or adjuvant $(p<0.01)$ (Table S2). 

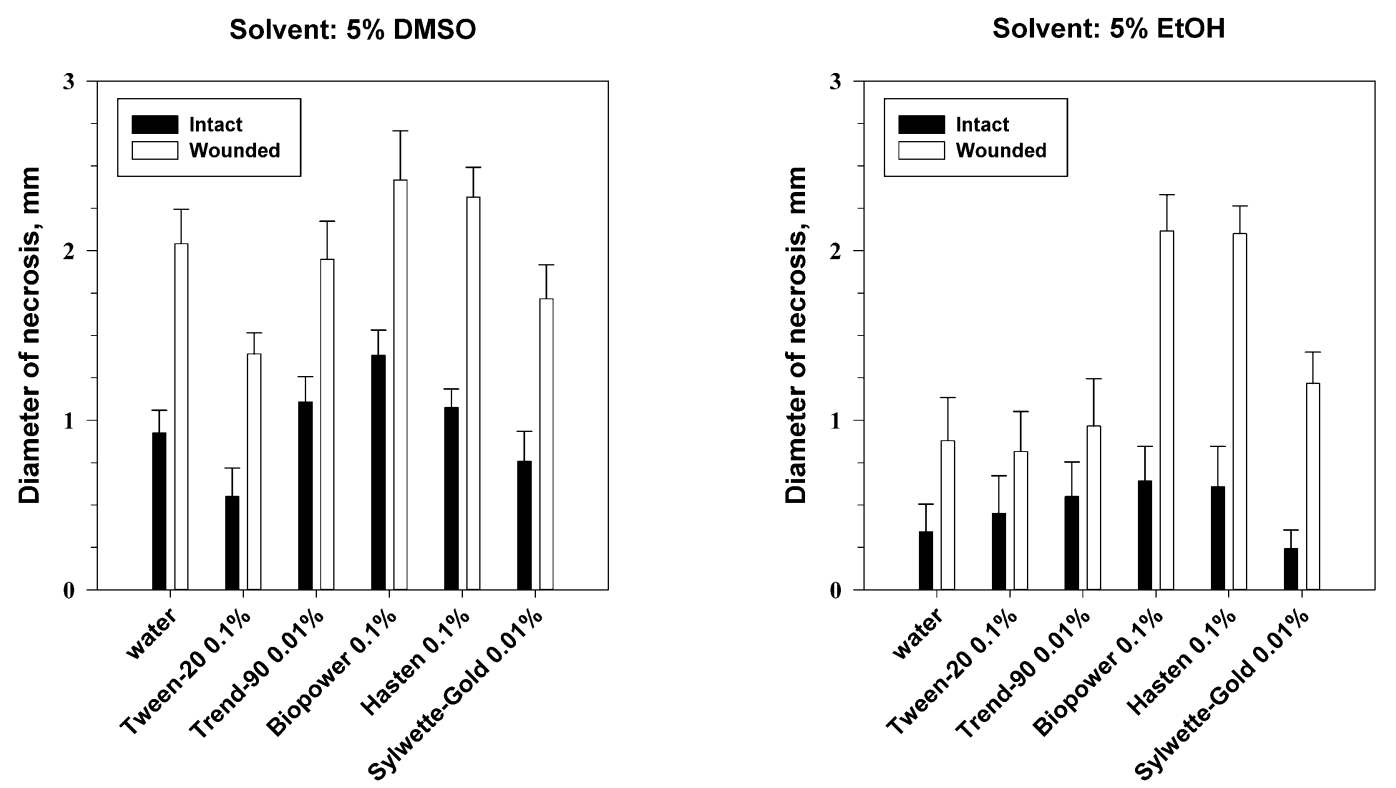

Figure 5. Effect of leaf damage, solvent and adjuvants on phytotoxicity of phaeosphaeride A on leaf discs of $C$. arvense. Least significant difference (LSD) $0.05=0.53$, bars indicate standard deviation at $p=0.05$.

When the toxin was dissolved in ethanol $(\mathrm{EtOH})$ its phytotoxic activity in the combination with Hasten or Biopower was significantly higher than the activity of phaeosphaeride A alone. Combinations of phaeosphaeride A, which was dissolved in DMSO, with Biopower and Hasten gave insignificant increase of its activity on both wounded and intact leaf discs of $C$. arvense. On the other hand, the addition of Tween-20 and Sylwett-Gold to the toxin solution slightly decreased phytotoxicity of phaeosphaeride $\mathrm{A}$ for $C$. arvense (Figure 5).

This experiment demonstrated that certain adjuvants can definitely inhibit (Tween-20) or to promote (Biopower and Hasten) the phytotoxic activity of phaeosphaeride A on leaf discs of C. arvense. The selection of adjuvants is species-specific: they are able to promote and inhibit the uptake of herbicidal compounds in certain plants [46]. According to the manufacturer, Hasten is a blend of esterified vegetable oil and non-ionic surfactants, however, little is known on efficacy of this adjuvant. A number of adjuvants enhanced the control of $C$. arvense by chemical herbicides, and there is some evidence that oil-based adjuvants are especially useful. Petroleum oil adjuvant added to clopyralid at $0.14 \mathrm{~kg} / \mathrm{ha}$ increased Canada thistle control to that achieved by clopyralid at 0.21 $\mathrm{kg} / \mathrm{ha}$ plus desmedipham/phenmedipham plus endothall [47]. Methylated seed oil was the best adjuvant to tribenuron to enhance its efficacy against common cocklebur and Canada thistle [48]. To our knowledge, there is a few of studies on effects of adjuvants on herbicidal activity of natural compounds. For instance, herbicidal activity of acetic acid, in particular, against $C$. arvense was improved by canola oil $(0.25 \% v / v)$ as an adjuvant [49]. Biopower (sodium lauryl sulfate) was shown to be useful in a number of herbicidal compositions for control of various weeds $[50,51]$.

\subsection{Effect of Adjuvants on Herbicidal Activity of Phaeosphaeride A}

Hasten and Biopower were evaluated with a combination of $0.5 \%$ semi-purified extract of the fungal solid culture containing about $50 \%$ of phaeosphaeride A. This semi-purified extract without adjuvants was shown to have weak herbicidal activity on aerial shoots of Cirsium arvense damaging about $35 \%$ of leaf surface. This effect was accompanied with insignificant decrease of dry weight of aerial shoots. Herbicidal effect of the extract with Biopower was considerably lower. In contrast, treatment of the plants with the extract with Hasten resulted in damage of ca. $80 \%$ of leaf surface and 3 -fold loss of dry weight comparing to control plants (Figure 6). 
A

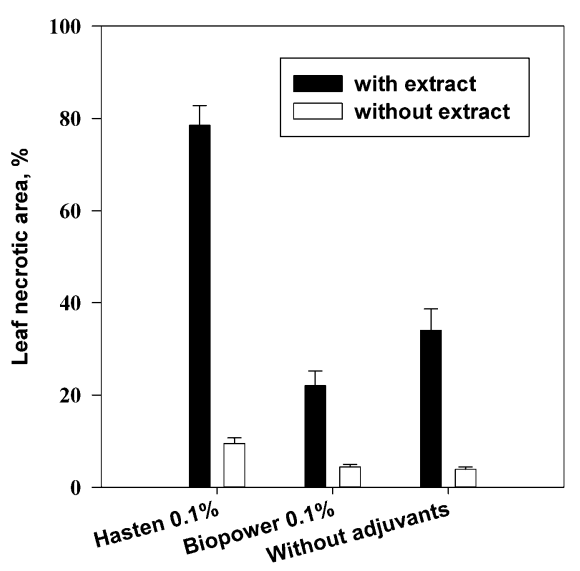

B

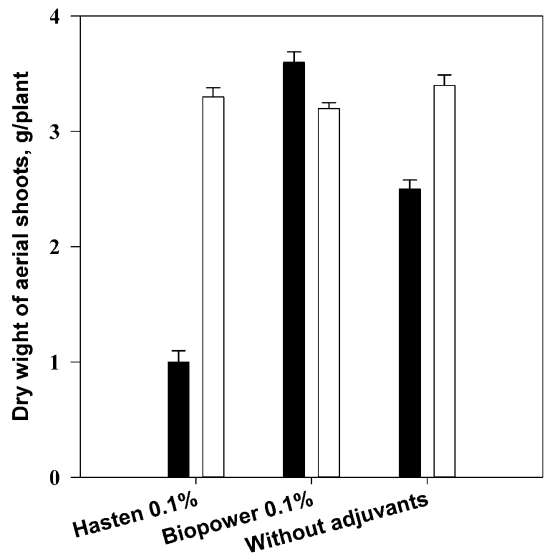

Figure 6. Effect of adjuvants on herbicidal activity of $0.5 \%$ semi-purified extract from solid culture of Paraphoma sp. VIZR 1.46 on C. arvense plants $48 \mathrm{~h}$ after treatment: (A) level of leaf damage $\left(\operatorname{LSD}_{0.05}=11.0\right),(\mathbf{B})$ dry biomass of aerial shots $\left(\operatorname{LSD}_{0.05}=1.8\right)$, bars indicate standard deviation at $p=0.05$.

This experiment supported Hasten as the adjuvant compatible with phaeosphaeride A. In contrast to the experiment with leaf discs of $C$. arvense, the adverse effect of Biopower on phytotoxic activity of phaeosphaeride $\mathrm{A}$ on the whole plants was observed. It can be explained by different application techniques used in this and previous experiments affected droplet size and penetration of the toxin in the leaf tissues. Moreover, both adjuvants were applied at the non-phytotoxic concentration $(0.1 \% v / v)$ that is lower than recommended concentrations of $0.5 \%$ and $0.25 \%$ for Hasten and Biopower respectively $[52,53]$. In the future, manipulation with the phytotoxin formulation including increasing concentration of adjuvants and addition of humectants like glycerol could enhance phytotoxicity and efficacy of phaeosphaeride A as a natural herbicidal compound [46].

\section{Material and Methods}

\subsection{General Experimental Procedures}

Optical rotations were measured using AA-55 polarimeter (Optical Activity, Ramsey, United Kingdom) in $\mathrm{CH}_{2} \mathrm{Cl}_{2}$. The UV spectra were measured in $\mathrm{MeCN}$ on a DU800 UV-vis spectrophotometer (Beckman Coulter, Brea, CA, USA). ${ }^{1} \mathrm{H}$ - and ${ }^{13} \mathrm{C}-\mathrm{NMR}$ spectra were recorded at 400 and $100 \mathrm{MHz}$, respectively, on a WM-400 spectrometer (Bruker, Billerica, $\mathrm{MA}, \mathrm{USA}$ ) in $\mathrm{CDCl}_{3}$, unless otherwise noted. The same solvent was used as the internal standard. COSY, ROESY, DEPT, HMBC and HMQC experiments [35] were recorded using Bruker microprograms. ESI-MS were obtained on a TSQ Quantum Access ${ }^{\mathrm{TM}}$ mass spectrometer (Thermo Fisher Scientific, Waltham, MA, USA). Analytical and PTLC were performed on silica gel plates (Kieselgel 60, F254, Merck, Darmstadt, Germany, 0.25 and $0.5 \mathrm{~mm}$, respectively). The spots were visualized exposure to UV radiation $(254 \mathrm{~nm})$. Column chromatography was performed on a silica gel (Kieselgel 60, 0.063-0.200 mm, Merck) Reverse phase column chromatography was carried out using a C-18ec Chromabond 10-g cartridge (Macherey-Nagel, Düren, Germany). Medium pressure liquid chromatography (MPLC) was performed with a Sepacore system (Büchi, Flawil, Switzerland) equipped with a UV-detector. Fractionation was performed with a PuriFlash SiHC cartridge ( $\mathrm{SiOH}, 40 \mathrm{~g}$, Interchim, Montluçon, France).

\subsection{Fungal Strain}

The fungus was isolated from necrotic leaf lesions in naturally infected $C$. arvense. The herbarium samples were collected from the Khabarovskiy region (Russian Federation) in 2006. The culture of the fungus Paraphoma sp. VIZR 1.46 was stored on potato-glucose-agar (PGA) slants in test tubes at 
$4{ }^{\circ} \mathrm{C}$. For the initial culture production, small pieces of mycelium were aseptically transferred to PGA plates and incubated for 14 days at $24^{\circ} \mathrm{C}$ in the dark. Mycelial plugs (about $5 \mathrm{~mm}$ in diameter) from the colony margins were used for inoculation of liquid and solid media. The DNA of the fungus, was extracted using Sambrook method [54] with Ultraclean Microbial DNA isolation kit (Mo Bio Laboratories, Carlsbad, CA, USA). For nucleotide sequence comparisons fragments of three loci were analysed: LSU, ITS, and TEF. Amplification of LSU was conducted utilizing the primer combination LR0R [55] and LR5 [56], EF1-728f and EF1-986R were used for TEF sequencing and the primer pair ITS1 and ITS4 [57] for ITS region. The PCRs were performed in a Tercik Thermal Cycler (DNA-Technology, Moscow, Russia) in a total volume of $25 \mu \mathrm{L}$. Sequence products were purified and subsequently separated and analysed on an ABI Prism 3500 DNA Sequencer (Applied Biosystems, Foster City, CA, USA). Consensus sequences were computed from the forward and reverse sequences using the BioEdit v. 7.2.5 software package (Ibis Biosciences, Carlsbad, CA, USA). The consensus sequences were deposited in GenBank (GenBank accession numbers KT289378, KT289379, KT289380).

\subsection{Production and Purification of Phytotoxic Metabolites}

\subsubsection{Liquid Culture}

YMG growth medium contained yeast extract $(4 \mathrm{~g})$, malt extract $(10 \mathrm{~g})$, glucose $(10 \mathrm{~g})$ and water $(1 \mathrm{~L})$. For seed culture the medium $(250 \mathrm{~mL}$ per $1000-\mathrm{mL}$ conical flask) was inoculated with two agar plugs cut off the 2-week fungal colony produced on PGA. The seed liquid cultures were incubated on the orbital shaker at $180 \mathrm{rpm}$ (revolution per minute) for seven days. The fermenter (20 L volume) containing $15 \mathrm{~L}$ of the same medium was inoculated with a suspension of the 7-day seed culture. After 10 days of the fermentation at $24{ }^{\circ} \mathrm{C}$ the culture fluid was separated from the mycelium by filtering through cheesecloth using a vacuum pump. The culture filtrates were extracted with ethyl acetate $(\mathrm{EtOAc})(2 \times 5 \mathrm{~L})$. The organic extracts were combined, dehydrated with $\mathrm{Na}_{2} \mathrm{SO}_{4}$, filtered and evaporated under reduced pressure to give a residue $970 \mathrm{mg}$ (yield $65 \mathrm{mg} / \mathrm{L}$ ). The extract was fractionated by column chromatography on silica gel (Merck 60, 0.040-0.063 mm) eluted with $n$-hexane-EtOAc from 100:0 to 0:100 $(v / v)$ in order of their increasing polarity, yielding 10 groups of homogenous fractions. The residues of $\mathrm{C}$ and $\mathrm{D}$ fraction groups showed phytotoxic activity and were fractionated on silica gel PTLC plates (Merck 60, $\mathrm{F}_{254}, 0.50 \mathrm{~mm}$,) with the eluent system $n$-hexane-EtOAc $(6: 4, v / v)$. This gave $15 \mathrm{mg}$ of one major metabolite $\left(\mathrm{R}_{\mathrm{f}} 0.6\right.$, yield $\left.1 \mathrm{mg} / \mathrm{L}\right)$ which was identified, as below reported, as curvulin (Figure 1A).

\subsubsection{Solid Culture}

Erlenmeyer flasks of $1 \mathrm{~L}$ volume (totally 18 flasks) containing $150 \mathrm{~g}$ of pearl barley and $100 \mathrm{~mL}$ of water were autoclaved at $121{ }^{\circ} \mathrm{C}$ for $30 \mathrm{~min}$. Each flask was inoculated with two agar plugs of the fungus. To avoid the balling of the infected substrate, the flasks were stirred up once every 2 days. After 30 days of incubation at $24^{\circ} \mathrm{C}$ in the dark the culture was dried with a stream of sterile air for 2 days at a room temperature. The dried material $(2.1 \mathrm{~kg})$ was extracted with the mixture acetone-water $(1: 1 v / v$, $7 \mathrm{~L}$ ). Acetone was evaporated under reduced pressure at $40^{\circ} \mathrm{C}$. The water residue was defatted with $n$-hexane $(3.5 \mathrm{~L})$ and then extracted with EtOAc $(3 \times 2.5 \mathrm{~L})$.

The combined organic extracts were dried $\left(\mathrm{Na}_{2} \mathrm{SO}_{4}\right)$, filtered and evaporated to dryness under reduced pressure at $40{ }^{\circ} \mathrm{C}$, yielding the oily residue $(4 \mathrm{~g})$. The latter was fractionated by reverse-phase column chromatography using a cartridge, eluted with $0.1 \%(v / v)$ of formic acid in deionized water followed by $25 \% \mathrm{MeCN}$ in $0.1 \%$ formic acid $(v / v)$. The final elution was performed with $50 \% \mathrm{MeCN}$ in $0.1 \%$ formic acid. The oily residue $(1 \mathrm{~g})$ obtained from this fraction was further purified by MPLC and the cartridge was eluted with n-hexane-EtOAc (gradient 0-80\% $v / v$ EtOAc) at a flow rate of $50 \mathrm{~mL} / \mathrm{min}$, collecting fractions of $10 \mathrm{~mL}$. The main metabolite was afforded $\left(\mathrm{R}_{\mathrm{f}} 0.5\right.$ in $\mathrm{CHCl}_{3}$-iso-PrOH 9:1 v/v, $351 \mathrm{mg}, 130 \mathrm{mg} / \mathrm{kg}$ ) and identified, as below reported, as phaeosphaeride A (Figure 1B). 


\subsection{Compound Characterization}

Curvulin (Figure 1A). White crystalline compound, UV $\lambda_{\max } 220,275,310 \mathrm{~nm} ;{ }^{1} \mathrm{H}-\mathrm{NMR} \delta$ $1.26(\mathrm{t}), 2.58$ (s), $3.86(\mathrm{~s}), 4.19$ (q), 6.28 (s), 6.34 (s), 8.17 (s), 12.83 (s); ${ }^{13} \mathrm{C}-\mathrm{NMR} \delta$ 13.9, 31.7, 41.7, 61.2, 103.0, 112.7, 115.7, 137.3, 161.6, 165.6, 170.6, 203.0; ESI-MS, $m / z 261[\mathrm{M}+\mathrm{Na}]^{+} ; 239[\mathrm{M}+\mathrm{H}]^{+}$, $211\left[\mathrm{M}+\mathrm{H}_{-} \mathrm{C}_{2} \mathrm{H}_{4}\right]^{+}, 197\left[\mathrm{M}+\mathrm{H}-\mathrm{CH}_{2} \mathrm{CO}\right]^{+}, 193\left[\mathrm{M}+\mathrm{H}_{-} \mathrm{C}_{2} \mathrm{H}_{5} \mathrm{OH}\right]^{+}, 165\left[\mathrm{M}+\mathrm{H}-\mathrm{C}_{2} \mathrm{H}_{5} \mathrm{CO}_{2} \mathrm{H}\right]^{+}, 123$ $\left[\mathrm{M}+\mathrm{H}-\mathrm{CH}_{2} \mathrm{CO}-\mathrm{HCO}_{2} \mathrm{C}_{2} \mathrm{H}_{5}\right]^{+}$.

Phaeosphaeride A (Figure 1B). Yellowish glass; $[\alpha]^{25} \mathrm{D}-108.33\left(\mathrm{c} 0.06, \mathrm{CH}_{2} \mathrm{Cl}_{2}\right) ; \mathrm{UV} \lambda_{\max } 262 \mathrm{~nm}$, ${ }^{1} \mathrm{H}-\mathrm{NMR}\left(\mathrm{DMSO}-d_{6}\right) \delta 0.86(\mathrm{t}, J=6.4 \mathrm{~Hz}, 3 \mathrm{H}), 1.19(\mathrm{~s}, 3 \mathrm{H}), 1.27(\mathrm{~m}, 2 \mathrm{H}), 1.49(\mathrm{~m}, 2 \mathrm{H}), 1.52(\mathrm{~m}, 2 \mathrm{H})$, $1.82(\mathrm{~m}, 2 \mathrm{H}), 3.80(\mathrm{~s}, 3 \mathrm{H}), 3.87(\mathrm{~d}, J=12.0 \mathrm{~Hz}, 1 \mathrm{H}), 4.09(\mathrm{~d}, J=12.0 \mathrm{~Hz}, 1 \mathrm{H}), 4.91(\mathrm{~s}, 1 \mathrm{H}), 4.98(\mathrm{~s}, 2 \mathrm{H})$, $5.43(\mathrm{~d}, J=12.0 \mathrm{~Hz}, 1 \mathrm{H}) ;{ }^{13} \mathrm{C}-\mathrm{NMR}\left(\mathrm{DMSO}-d_{6}\right) \delta 13.9,20.4,20.0,26.1,27.6,30.9,63.8,64.4,71.0,86.3$, 90.8, 104.8, 137.1, 155.3, 166.5; ESI-MS, $m / z 320[\mathrm{M}+\mathrm{Na}]^{+}, 298[\mathrm{M}+\mathrm{H}]+, 280\left[\mathrm{M}+\mathrm{H}_{-} \mathrm{H}_{2} \mathrm{O}\right]^{+}, 262$ $\left[\mathrm{M}+\mathrm{H}-2 \mathrm{H}_{2} \mathrm{O}\right]^{+}$.

\subsection{Biological Assays}

Phytotoxic activity was studied using leaf disc-puncture bioassay as previously described [10]. The purified metabolites were tested at a range of concentrations from 0.125 to $2 \mathrm{mg} / \mathrm{mL}(42-840 \mu \mathrm{M})$. The samples were dissolved in $\mathrm{EtOH}$ and adjusted to the desired concentration with distilled water. The final concentration of the solvent was $5 \% v / v$, which was not phytotoxic. The leaf discs $(1 \mathrm{~cm}$ diameter) of dicotyledonous plants and the leaf segments of monocotyledonous plants ( $2 \mathrm{~cm}$ length) were collected from well expanded leaves, placed on the moistened general purpose filter paper ("F", Bashkhimservis, Russia) in transparent plastic boxes and wounded in the center with a sharp needle. The selectivity of compounds curvulin (at concentration $840 \mu \mathrm{M}$ ) and phaeosphaeride A (at concentration $335 \mu \mathrm{M}$ ) was studied using plants of different families: Cirsium arvense, Helianthus annuus, Cynara scolymus (Asteraceae), Arabidopsis thaliana (Brassicaceae), Heracléum sosnówskyi (Umbelliferae), Pisum sativum (Fabaceae), Chenopodium album (Chenopodiaceae), Cucurbita pepo (Cucurbitaceae), Elytrigia repens, Triticum aestivum (Poaceae). These concentrations were chosen based on preliminary phytotoxicity tests. Droplets $(10 \mu \mathrm{L})$ of the test solution were applied on the discs and then incubated for two days under artificial light (12 h day $/ 12 \mathrm{~h}$ night) and at a controlled temperature $\left(24{ }^{\circ} \mathrm{C}\right.$ day $/ 20^{\circ} \mathrm{C}$ night). Due to different leaf shape the diameter and length of necrotic lesions was measured when used leaf discs of dicot species and leaf segments of monocot plant species respectively. Ten replicate leaf discs/segments were used for each treatment. Experiments were conducted twice.

For root growth inhibition bioassay seeds of radish (Raphanus sativus), lettuce (Lactuca sativa), chicory (Cichorium endivia) were surface sterilized with $70 \% \mathrm{EtOH}$ and incubated on moistened filter paper in a wetness chamber for germination at the temperature $25^{\circ} \mathrm{C}$ in the darkness. Seedling with rootlets of 1-2 mm length were soaked in the solutions of phytotoxins $(0.001-1 \mathrm{mg} / \mathrm{mL})$, which were prepared as described above, for $1 \mathrm{~h}$, than washed by water and incubated at $25^{\circ} \mathrm{C}$ in the darkness. The length of rootlets measured $48 \mathrm{~h}$ post treatment. Phytotoxic activity (A) calculated by the formula: $A=100-\left(\frac{\mathrm{LE} 48-\mathrm{LEo}}{\mathrm{LC} 48-\mathrm{LCo}} \times 100\right)$, where $\mathrm{LE}_{0}$ and $\mathrm{LE}_{48}$ - means of rootlet length zero and $48 \mathrm{~h}$ post treatment in the experiment, $\mathrm{LC}_{0}$ and $\mathrm{LC}_{48}$-means of rootlet length zero and $48 \mathrm{~h}$ post treatment.

The antimicrobial activity of curvulin and phaeosphaeride A was tested using the paper disc technique according to the already described protocol [58]. A preliminary study was conducted with three test microorganisms: Gram-positive (B. subtilis) and Gram-negative (Xanthomonas campestris) bacteria, and the yeast fungus (Candida tropicalis). Additional test organisms were used for characterization of phaeosphaeride A: Gram-positive (Clavibacter michicagenis) and Gram-negative bacteria (Pseudomonas corrugate, Erwinia carotovora, Pseudomonas syringae pv. maculicola, P. syringae pv. tomato) mycelial phytopathogenic fungi (Sclerotinia sclerotiorum and Botrytis cinerea). The studied bacteria were grown on medium, consisted of pancreatic sprat hydrolysate $17.9 \mathrm{~g} / \mathrm{L}$, microbiological agar $11.2 \mathrm{~g} / \mathrm{L}$, and sodium chloride 7.7 g/L (Microgen, Moscow, Russia), while the fungi were grown 
on PGA. Up to $100 \mu \mathrm{g}$ of each metabolite was applied per disc. The fungal and bacterial cultures were incubated at $24{ }^{\circ} \mathrm{C}$ and $30{ }^{\circ} \mathrm{C}$, respectively, for $48 \mathrm{~h}$ and inhibition zones were measured daily.

Zootoxic activity assay. The zootoxic activity was evaluated on Paramecium caudatum by using the protocol already described [45]. Both phytotoxins were tested at concentrations of 4, 40, and $400 \mu \mathrm{M}$ in $5 \% \mathrm{EtOH}$, with three replications for each concentration of every compound. The assay was performed in a 24-well plate. A suspension of P. caudatum cells $(900 \mu \mathrm{L})$ and $100 \mu \mathrm{L}$ of stock solutions of curvulin and phaeosphaeride A prepared in 50\% EtOH were poured to each well. In the control treatment, $100 \mu \mathrm{L}$ of $50 \% \mathrm{EtOH}$ was added to $900 \mu \mathrm{L}$ of suspension with paramecia. The culture of paramecia was incubated at $24 \pm 1^{\circ} \mathrm{C}$. Toxic effects of curvulin and phaeosphaeride $\mathrm{A}$ on paramecia movement was observed after 3 and $30 \mathrm{~min}, 3 \mathrm{~h}$ and $24 \mathrm{~h}$ post treatment. The toxicity was expressed as percentage of dead paramecia in reference to the total amount.

\subsection{Effects of Leaf Wounding, Solvents and Adjuvants on Phytotoxic Activity of Phaeosphaeride A}

Four different non-ionic adjuvants Trend-90 (isodecyl alcohol ethoxylate, Du Pont, Geneva, Switzerland), Tween-20 (polyoxyethylene sorbitol ester, Croda Crop., Snaith, United Kingdom), Sylwette-Gold (trisiloksanakoksilate, Chemtura, Philadelphia, PA, USA) and Hasten (ethyl and methyl esters of vegetable oil, Victorian Chemicals, Coolaroo, Australia) and one anionic adjuvant Biopower (sodium lauryl sulphate, Bayer CropScience Limited, Cambridge, United Kingdom) were selected for this experiment. Solutions of the adjuvants were prepared in distilled water in following concentrations $(v / v)$ : 0.1\% Tween-20, 0.1\% Biopower, 0.01\% Trend-90, 0.01\% Sylwette-Gold, $0.1 \%$ Hasten. Preliminary experiments indicated these concentrations of adjuvants to be nontoxic when tested on leaf discs of C. arvense and leaf segments of E. repens. The purified compund ( $0.2 \mathrm{mg})$ was dissolved in $10 \mu \mathrm{L}$ of EtOH or DMSO and adjusted to the volume of $200 \mu \mathrm{L}$ with one of the adjuvant solution or water. A $10 \mu \mathrm{L}$ droplet of the test solution was applied on each wounded and intact leaf disc/segment of C. arvense/E. repens. Two days post treatment the diameter/length of necrotic lesions was measured. Ten replicate leaf discs/segments were used for each treatment.

The herbicidal effect of three formulations of phaeosphaeride A was evaluated on plants of C. arvense at the stage of rosette. The underground shoots of the weed (cuttings $5 \mathrm{~cm} \mathrm{length)} \mathrm{were}$ planted in pots with a soil mixture and incubated in a greenhouse at approximately $24{ }^{\circ} \mathrm{C}$ for 4 weeks. A semi-purified extract containing approximately $50 \%$ of the phytotoxin (determined by HPLC) was obtained by passing the crude extract from solid culture of Paraphoma sp. VIZR 1.46 through C18 cartridge as described above. The dry residue $(240 \mathrm{mg})$ of the semi-purified extract was dissolved in $2.4 \mathrm{~mL}$ of DMSO. This solution was divided in three parts of $0.8 \mathrm{~mL}$, each of them was diluted to the volume of $16 \mathrm{~mL}$ with water or $0.1 \%$ solution $(v / v)$ of the adjuvant (Biopower or Hasten). The final concentrations of the extract and DMSO were $0.5 \%(w / v)$ and $5 \%(v / v)$ respectively. The formulations of phaeosphaeride A were sprayed onto plants with a hand atomizer $(6 \mathrm{~mL}$ per pot with 3 plants, 3 replicate pots per treatment). The dosage of phaeosphaeride A was about $0.05 \mathrm{~mol} / \mathrm{m}^{2}$. The $5 \%$ DMSO water solution without and with the adjuvants (Biopower or Hasten, $0.1 \% v / v$ ) were used as control treatments. The sprayed plants were incubated at the temperature $24^{\circ} \mathrm{C}$ and 12 -h photoperiod. Injury level and biomass loss were observed $48 \mathrm{~h}$ after treatment. The rate of leaf damage was evaluated using visual scale from 0 (no symptoms) to 100\% (all leaves are necrotic). Aerial shoots of the treated and control plants of $C$. arvense were cut and dried at room temperature to a constant weight.

\subsection{Data Analysis}

All of the bioassays were performed three times. Data were subjected to one-way and two-way ANOVA followed by comparison of multiple treatment levels with the control applying the least significant difference (LSD) at $p=95 \%$. All the statistical analyses were performed using Statistica 8.0 (StatSoft, Tusla, OK, USA). 


\section{Conclusions}

Curvulin and phaeosphaeride A were isolated for the first time as phytotoxic metabolites from Paraphoma sp. VIZR 1.46 liquid and solid cultures, respectively. Curvulin showed a weak nonselective phytotoxic activity when assayed on ten plant species in a concentration of $8.4 \times 10^{-4} \mathrm{M}$, matching data reported earlier for this compound [36-39]. Despite being nontoxic against the tested bacteria, fungi and paramecia, further research work with curvulin seems to be unpromising in light of the weak phytotoxicity of this compound. Phaeosphaeride A on the other hand demonstrated a high level of nonselective toxicity on all the tested plants. The phytotoxic activity of this compound identified as phyllostictine B was reported earlier when tested on Canada thistle at a concentration of $6 \times 10^{-3} \mathrm{M}$ [26]. It was shown to be inactive against the tested bacteria and fungi and weakly toxic against ciliates and these results are in accordance with data reported earlier [26]. Further studies are needed to elucidate the mode of action of phaeosphaeride A. Research is in progress to evaluate the possibility of enhancing the phytotoxic activity of this compound for intact plants as well to optimize its production. Our results have shown that addition of some adjuvants, including Hasten and Biopower, allowed increasing activity of the toxin on intact leaf discs of $C$. arvense. The herbicidal effect of the $0.5 \%$ semi-purified extract of solid culture of Paraphoma sp. VIZR 1.46 in combination with Hasten $(0.1 \%)$ was strong causing fast leaf damage and 3-fold loss of dry mass of aerial shoots. These results can open the opportunity for further selection of appropriate adjuvants and their concentrations for increasing efficacy and potential of other natural herbicides.

Supplementary Materials: Supplementary data are available online. Figure S1: A Bayesian 50\% majority rule consensus tree based on dataset of LSU alignment of cf. Paraphoma sp. VIZR 1.46 and related species (1); Figure S2: A Bayesian 50\% majority rule consensus tree based on dataset of LSU alignment of cf Paraphoma sp. VIZR 1.46 and related species (2); Figure S3: Point differences in nucleotide sequences of LSU for strains Paraphoma sp. 1.46, P. chrysanthemicola CBS 522.66, P. radicina CBS 102,875 and P. vinacea UMPV 003; Figure S4: UV spectrum of curvulin, dissolved in MeCN; Figure S5: ESI Mass spectrum of curvulin, recorded in positive mode; Figure S6: ${ }^{1} \mathrm{H}-\mathrm{NMR}$ spectrum of curvulin $\left(\mathrm{CDCl}_{3}\right.$, at $\left.400 \mathrm{MHz}\right)$; Figure S7: ${ }^{13} \mathrm{C}-\mathrm{NMR}$ spectrum of curvulin $\left(\mathrm{CDCl}_{3}\right.$, at $100 \mathrm{MHz}$ ); Figure S8: UV spectrum of phaeosphaeride A, dissolved in acetonitrile; Figure S9: ESI Mass spectrum of phaeosphaeride A, recorded in positive mode; Figure S10: ${ }^{1} \mathrm{H}-\mathrm{NMR}$ spectrum of phaeosphaeride A (DMSO $d_{6}$, at $400 \mathrm{MHz}$ ); Figure S11: ${ }^{13} \mathrm{C}-\mathrm{NMR}$ spectrum of phaeosphaeride A (DMSO- $d_{6}$, at $100 \mathrm{MHz}$ ); Figure S12: ${ }^{13} \mathrm{C}-\mathrm{DEPT}$ spectrum of phaeosphaeride A (DMSO- $d_{6}$, at $100 \mathrm{MHz}$ ); Figure S13: ${ }^{1} \mathrm{H},{ }^{1} \mathrm{H}-\mathrm{COSY}$ spectrum of phaeosphaeride A $\left(\mathrm{DMSO} d_{6}, 100,6 \mathrm{MHz}\right.$ ); Figure S14: ${ }^{1} \mathrm{H},{ }^{13} \mathrm{C}-\mathrm{HMQC}$ spectrum of phaeosphaeride A (DMSO $\left.d_{6}\right)$; Figure S15: ${ }^{1} \mathrm{H}$, ${ }^{13} \mathrm{C}$-HMBC spectrum of phaeosphaeride A (DMSO- $d_{6}$ ); Figure S16: ${ }^{1} \mathrm{H},{ }^{1} \mathrm{H}$-ROESY spectrum of phaeosphaeride A (DMSO- $d_{6}, 400 \mathrm{MHz}$ ); Figure S17: (a) Structure of for phaeosphaeride A (2) (numbering of atoms is given according to to those given by Maloney et al., 2006 [41] Selected ROESY $\left({ }^{1} \mathrm{H}\right.$-to $\left.{ }^{1} \mathrm{H}\right)$ NMR correlations; Table S1: ${ }^{1} \mathrm{H}$ - and ${ }^{13} \mathrm{C}-\mathrm{NMR}$ data of phaeosphaeride A (2 in DMSO- $d_{6}$ ); Table S2: Summary of three-way ANOVA analysis of the effect of adjuvants, solvents and wounding on phytotoxicity of phaeosphaeride $\mathrm{A}$ against $\mathrm{C}$. arvense; Figure S18: Effect of adjuvants on herbicidal activity of $0.5 \%$ semi-purified extract (ca. $0.25 \%$ phaeosphaeride A) from solid state culture of Paraphoma sp. VIZR 1.46 on Cirsium arvense plants ( $48 \mathrm{~h}$ after treatment).

Author Contributions: E.P. performed the research and wrote a draft of the manuscript; Y.T. and S.S. carried out the molecular identification of the fungus; L.C. recorded the spectra; A.B. planned and performed the research; A.E. and A.B. finalized the draft and revised the manuscript. All authors read and approved the final manuscript.

Funding: This research was funded by Russian Science Foundation (project No. 16-16-00085) and in a part (preliminary studies) by Deutscher Akademischer Austauschdienst (for A.B.).

Acknowledgments: Authors (A.B. and E.P.) acknowledged Eckhard Thines (Institute of Biotechnology and Drug Research, IBWF, Kaiserslautern, Germany) for valuable start points of the work. A.E. is associated to Istituto di Chimica Biomolecolare del CNR, Pozzuoli, Italy.

Conflicts of Interest: The authors declare no conflict of interest.

Patents: The research resulted in two patents (RU No. 2596928 and RU No. 2619300).

\section{References}

1. Nicolopoulou-Stamati, P.; Maipas, S.; Kotampasi, C.; Stamatis, P.; Hens, L. Chemical pesticides and human health: The urgent need for a new concept in agriculture. Front. Public Health 2016, 4, 148. [CrossRef] [PubMed] 
2. Westwood, J.H.; Charudattan, R.; Duke, S.O.; Fennimore, S.A.; Marrone, P.; Slaughter, D.C.; Swanton, C.; Zollinger, R. Weed management in 2050: Perspectives on the future of weed science. Weed Sci. 2018, 66, 275-285. [CrossRef]

3. Sparks, T.C.; Hahn, D.R.; Garizi, N.V. Natural products, their derivatives, mimics and synthetic equivalents: Role in agrochemical discovery. Pest Manag. Sci. 2017, 73, 700-715. [CrossRef] [PubMed]

4. Chen, S.; Qiang, S. Recent advances in tenuazonic acid as a potential herbicide. Pesticide Biochem. Physiol. 2017, 143, 252-257. [CrossRef] [PubMed]

5. Duke, S.O.; Dayan, F.E. Discovery of new herbicide modes of action with natural phytotoxins. In Discovery and Synthesis of Crop Protection Products; Maienfisch, P., Stevenson, T.M., Eds.; American Chemical Society: Washington, DC, USA, 2015; pp. 79-92. ISBN 9780841231023.

6. Cimmino, A.; Masi, M.; Evidente, M.; Superchi, S.; Evidente, A. Fungal phytotoxins with potential herbicidal activity: Chemical and biological characterization. Nat. Prod. Rep. 2015, 32, 1629-1653. [CrossRef] [PubMed]

7. Pusztahelyi, T.; Holb, I.J.; Pócsi, I. Secondary metabolites in fungus-plant interactions. Front. Plant Sci. 2015, 6, 1-23. [CrossRef] [PubMed]

8. Berestetskiy, A.O. A review of fungal phytotoxins: From basic studies to practical use. Appl. Biochem. Microbiol. 2008, 44, 453-465. [CrossRef]

9. Rivero-Cruz, F.J.; García-Aguirre, G.; Cerda-García-Rojas, C.M.; Mata, R. Conformational behavior and absolute stereostructure of two phytotoxic nonenolides from the fungus Phoma herbarum. Tetrahedron 2000, 56, 5337-5344. [CrossRef]

10. Graupner, P.R.; Carr, A.; Clancy, E.; Gilbert, J.; Bailey, K.L.; Derby, J.; Gerwick, B.C. The Macrocidins: Novel cyclic tetramic acids with herbicidal activity produced by Phoma macrostoma. J. Nat. Prod. 2003, 66, 1558-1561. [CrossRef] [PubMed]

11. Cimmino, A.; Andolfi, A.; Berestetskiy, A.; Evidente, A. Production of phytotoxins by Phoma exigua var. exigua, a potential mycoherbicide against perennial thistles. J. Agric. Food Chem. 2008, 56, 6304-6309. [CrossRef] [PubMed]

12. Cimmino, A.; Andolfi, A.; Zonno, M.C.; Avolio, F.; Berestetskiy, A.; Vurro, M.; Evidente, A. Chenopodolans A-C: Phytotoxic furopyrans produced by Phoma chenopodiicola, a fungal pathogen of Chenopodium album. Phytochemistry 2013, 96, 208-213. [CrossRef] [PubMed]

13. Cimmino, A.; Andolfi, A.; Zonno, M.C.; Avolio, F.; Santini, A.; Tuzi, A.; Berestetskyi, A.; Vurro, M.; Evidente, A. Chenopodolin: A phytotoxic unrearranged ent-pimaradiene diterpene produced by Phoma chenopodicola, a fungal pathogen for Chenopodium album biocontrol. J. Nat. Prod. 2013, 76, 1291-1297. [CrossRef] [PubMed]

14. Smith, S.C. Combinatorial chemistry in the development of new crop protection products. Pestic. Outlook 2003, 14, 21-25. [CrossRef]

15. Berestetskii, A.O.; Yuzikhin, O.S.; Katkova, A.S.; Dobrodumov, A.V.; Sivogrivov, D.E.; Kolombet, L.V. Isolation, identification, and characteristics of the phytotoxin produced by the fungus Alternaria cirsinoxia. Appl. Biochem. Microbiol. 2010, 46, 75-79. [CrossRef]

16. Fumagalli, P.; Andolfi, A.; Avolio, F.; Boari, A.; Cimmino, A.; Finizio, A. Ecotoxicological characterisation of a mycoherbicide mixture isolated from the fungus Ascochyta caulina. Pest Manag. Sci. 2013, 9, 850-856. [CrossRef] [PubMed]

17. Radivojević, L.; Gašić, S.; Umiljendić, J.G.; Šantrić, L.; Brkić, D. Impact of Different Adjuvants and Modes of Application on Efficacy of Rimsulfuron in Maize. Pestic. Phytomed. 2011, 26, 255-263. [CrossRef]

18. Yilmaz, G.; Dane, F. Phytotoxicity Induced by Herbicide and Surfactant on stomata and epicuticular wax of Wheat. Rom. Biotechnol. Lett. 2012, 17, 7757-7765.

19. Gitsopoulos, T.K.; Damalas, C.A.; Georgoulas, I. Improving diquat efficacy on grasses by adding adjuvants to the spray solution before use. Planta Daninha 2014, 32, 355-360. [CrossRef]

20. Gurtovenko, A.; Anwar, J. Modulating the structure and properties of cell membranes: The molecular mechanism of action of dimethyl sulfoxide. J. Phys. Chem. B 2007, 111, 10453-10460. [CrossRef] [PubMed]

21. Berestetskyi, A.O.; Kurlenya, A.S. Antimicrobial properties of phytopathogenic mycromycetes. Mycol. Phytopathol. 2014, 48, 123-134.

22. Phookamsak, R.; Liu, J.; McKenzie, E.H.C.; Manamgoda, D.S.; Ariyawansa, H.; Thambugala, K.M.; Dai, D.; Camporesi, E.; Chukeatirote, E.; Wijayawardene, N.N.; et al. Revision of Phaeosphaeriaceae. Fungal Divers. 2014, 68, 159-238. [CrossRef] 
23. Moslemi, A.; Ades, P.K.; Groom, T.; Crous, P.W.; Nicolas, M.E.; Taylor, P.W.J. Paraphoma Crown Rot of Pyrethrum (Tanacetum cinerariifolium). Plant Dis. 2016, 100, 2363-2369. [CrossRef]

24. Boerema, G.H.; Gruyter, J.; Noordeloos, M.E.; Hamers, M.A. Phoma Identification Manual: Differentiation of Specific and Infraspecific Taxa in Culture; CABI Publishing: Wallingford/Cambridge, UK, 2004; p. 470.

25. Kluth, S.; Kruess, A.; Tscharntke, T. Effects of two pathogens on the performance of Cirsium arvense in a successional fallow. Weed Res. 2005, 45, 261-269. [CrossRef]

26. Evidente, A.; Cimmino, A.; Andolfi, A.; Vurro, M.; Zonno, M.C.; Cantrell, C.L.; Motta, A. Phyllostictines A-D, oxazatricycloalkenones produced by Phyllosticta cirsii, a potential mycoherbicide for Cirsium arvense biocontrol. Tetrahedron 2008, 64, 1612-1619. [CrossRef]

27. Evidente, A.; Cimmino, A.; Berestetskiy, A.; Andolfi, A.; Motta, A. Stagonolides G-I and modiolide A, nonenolides produced by Stagonospora cirsii, a potential mycoherbicide for Cirsium arvense. J. Nat. Prod. 2008, 71, 1897-1901. [CrossRef] [PubMed]

28. Trenti, F.; Cox, R.J. Structural revision and biosynthesis of the fungal phytotoxins phyllostictines A and B. J. Nat. Prod. 2017, 80, 1235-1240. [CrossRef] [PubMed]

29. Kenfield, D.; Hallok, Y.; Clard, J.; Strobel, G. Curvulin and o-methylcurvulinic acid: Phytotoxic metabolites of Dreshlera indica which cause necroses on purslane and spiny amaranth. Plant Sci. 1989, 60, 123-127. [CrossRef]

30. Kamal, A.; Khan, M.A.; Qureshi, A. Studies in the biochemistry of microorganisms-II Constitution of curvulin, curvulinic acid and curvulol, metabolic products of Curvularia siddiqui. Tetrahedron 1963, 19, 111-115. [CrossRef]

31. Kamal, A.; Ahmad, N.; Ali Khan, M.; Qureshi, H. Studies in the biochemistry of microorganisms-I. Curvulin and curvulinic acid, metabolic products of Curvularia siddiqui. Tetrahedron 1962, 18, 433-436. [CrossRef]

32. Varma, G.B.; Fatope, M.O.; Marwah, R.G.; Deadman, M.E.; Al-Rawahi, F.K. Production of phenylacetic acid derivatives and 4-epiradicinol in culture by Curvularia lunata. Phytochemistry 2006, 67, 1925-1930. [CrossRef] [PubMed]

33. de Almeida, T.T.; Ribeiro, M.A.; Polonio, J.C.; Garcia, F.P.; Nakamura, C.V.; Meurer, E.C.; Sarragiotto, M.H.; Baldoqui, D.C.; Azevedo, J.L.; Pamphile, J.A. Curvulin and spirostaphylotrichins R and U from extracts produced by two endophytic Bipolaris sp. associated to aquatic macrophytes with antileishmanial activity. Nat. Prod. Res. 2017, 26, 1-8. [CrossRef] [PubMed]

34. Maloney, K.N.; Hao, W.; Xu, J.; Gibbons, J.; Hucul, J.; Roll, D.; Brady, S.F.; Schroeder, F.C.; Clardy, J. Phaeosphaeride A, an inhibitor of STAT3-dependent signaling isolated from an endophytic fungus. Org. Lett. 2006, 4067-4070. [CrossRef] [PubMed]

35. Berger, S.; Braun, S. 200 and More Basic NMR Experiments: A Practical Course, 1st ed; Wiley-VCH: Weinheim, Germany, 2004; p. 838. ISBN 3-527-31067-3.

36. Kobayashi, K.; Okamoto, I.; Morita, N.; Kiyotani, T.; Tamura, O. Synthesis of the proposed structure of phaeosphaeride A. Org. Biomol. Chem. 2011, 9, 5825-5832. [CrossRef] [PubMed]

37. Chatzimpaloglou, A.; Yavropoulou, M.P.; Rooij, K.E.; Biedermann, R.; Mueller, U.; Kaskel, S.; Sarli, V. Total synthesis and biological activity of the proposed structure of phaeosphaeride A. J. Org. Chem. 2012, 77, 9659-9667. [CrossRef] [PubMed]

38. Kobayashi, K.; Kobayashi, Y.; Nakamura, M.; Tamura, O.; Kogen, H. Establishment of relative and absolute configurations of phaeosphaeride A: Total synthesis of ent-phaeosphaeride A. J. Org. Chem. 2015, 80, 1243-1248. [CrossRef] [PubMed]

39. Abzianidze, V.V.; Efimova, K.P.; Poluektova, E.V.; Trishin, Y.G.; Kuznetsov, V.A. Synthesis of natural phaeosphaeride A and semi-natural phaeosphaeride B derivatives. Mendeleev Commun. 2017, 27, 490-492. [CrossRef]

40. Abzianidze, V.V.; Poluektova, E.V.; Bolshakova, K.P.; Panikorovskii, T.L.; Bogachenkov, A.S.; Berestetskiy, A.O. Crystal structure of natural phaeosphaeride A. Acta Cryst. 2015, E71, o625. [CrossRef] [PubMed]

41. Kobayashi, K.; Tanaka, K.; Kogen, H. Total Synthesis and Biological Evaluation of Phaeosphaerides. Catalysts 2018, 8, 206. [CrossRef]

42. Masi, M.; Meyer, S.; Clement, S.; Andolfi, A.; Cimmino, A.; Evidente, A. Spirostaphylotrichin W, a spirocyclic $\gamma$-lactam isolated from liquid culture of Pyrenophora semeniperda, a potential mycoherbicide for cheatgrass (Bromus tectorum) biocontrol. Tetrahedron 2014, 70, 1497-1501. [CrossRef] 
43. Abraham, W.R.; Meyer, M. Curvupallides, a new class of alkaloids from the fungus Curvularia pallescens. Tetrahedron 1995, 51, 4947-4952. [CrossRef]

44. Li, C.S.; Ding, Y.; Yang, B.J.; Miklossy, G.; Yin, H.Q.; Walker, L.A.; Turkson, J.; Cao, S. A new metabolite with a unique 4-pyranone- $\gamma$-lactam-1,4-thiazine moiety from a hawaiian-plant associated fungus. Org. Lett. 2015, 17, 3556-3559. [CrossRef] [PubMed]

45. Yuzikhin, O.; Mitina, G.; Berestetskiy, A. Herbicidal potential of stagonolide, a new phytotoxic nonenolide from Stagonospora cirsii. J. Agric. Food Chem. 2007, 55, 7707-7711. [CrossRef] [PubMed]

46. Field, R.J.; Dobson, N.N.; Tisdall, L.J. Species-specific sensitivity to organosilicone surfactant-enhancement of glyphosate uptake. In Adjuvants for Agrichemicals; Foy, C.L., Ed.; CRC Press, Inc.: Boca Raton, FL, USA, 1992; pp. 423-431. ISBN 9781351077958.

47. Webber, C.L., III; White, P.M., Jr.; Shrefler, J.W.; Spaunhorst, D.J. Impact of acetic acid concentration, application volume, and adjuvants on weed control efficacy. J. Agric. Sci. 2018, 10, 1-6. [CrossRef]

48. Renner, K.A. Canada thistle (Cirsium arvense) control in sugarbeet with clopyralid. Weed Technol. 1991, 5, 392-395. [CrossRef]

49. Zollinger, R.K. Influence of adjuvants on weed control from tribenuron. J. ASTM Int. 2005, 2, 1-7. [CrossRef]

50. Lockett, J.; Morgan, C. Herbicide Composition. European Patent N 1981339B1, 29 February 2012. Available online: https:/ / patents.google.com/patent/EP1981339B1/zh-cn (accessed on 22 October 2018).

51. Fanigliulo, A.; Filì, V.; Crescenzi, A. Evaluation of efficacy and effect of application timing of a new herbicide, a.i. propoxy- carbazone + iodosulfuron + mefenpyr on Triticum durum. Commun. Agric. Appl. Biol. Sci. 2012, 77, 483-488. [PubMed]

52. Papapanagiotou, A.P.; Kaloumenos, N.S.; Eleftherohorinos, I.G. Sterile oat (Avena sterilis L.) cross-resistance profile to ACCase-inhibiting herbicides in Greece. Crop Prot. 2012, 35, 118-126. [CrossRef]

53. Ferguson, J.C.; Chechetto, R.G.; Adkins, S.W.; Hewitt, A.J.; Chauhan, B.S.; Kruger, G.R.; O'Donnell, C.C. Effect of spray droplet size on herbicide efficacy on four winter annual grasses. Crop Prot. 2018, 112, 118-124. [CrossRef]

54. Sambrook, E.A.; Fritsch, E.F.; Maniatis, T. Molecular Cloning: A Laboratory Manual; Cold Spring Harbor Laboratory Press: New York, NY, USA, 1989; p. 479.

55. Rehner, S.A.; Samuels, G.J. Taxonomy and phylogeny of Gliocladium analysed from nuclear large subunit ribosomal DNA sequences. Mycol. Res. 1994, 98, 625-634. [CrossRef]

56. Vilgalys, R.; Hester, M. Rapid genetic identification and mapping of enzymatically amplified ribosomal DNA from several Cryptococcus species. J. Bacteriol. 1990, 172, 4238-4246. [CrossRef] [PubMed]

57. White, T.J.; Bruns, T.; Lee, S.; Taylor, J. Amplification and direct sequencing of fungal ribosomal RNA genes for phylogenetics. In PCR Protocols: A Guide to Methods and Applications; Innis, M.A., Gelfand, D.H., Sninsky, J.J., White, T.J., Eds.; Academic Press: New York, NY, USA, 1990; pp. 315-322.

58. Arullappan, S.; Zakaria, Z.; Basri, D.F. Preliminary screening of antibacterial activity using crude extracts of Hibiscus rosa sinensis. Trop Life Sci. Res. 2009, 20, 109-118. [PubMed]

Sample Availability: Samples of the compounds are available from the authors.

(C) 2018 by the authors. Licensee MDPI, Basel, Switzerland. This article is an open access article distributed under the terms and conditions of the Creative Commons Attribution (CC BY) license (http:// creativecommons.org/licenses/by/4.0/). 